\title{
Seasonal Variation of Some Physico-chemical Characteristics of Three Major Riversin Imphal, Manipur: A Comparative Evaluation
}

\author{
TH. ALEXANDER SINGH ${ }^{1}$, N.SANAMACHA MEETEI ${ }^{2}$, and L. BIJEN MEITEI* \\ ${ }^{1}$ Research Scholar, CMJ University, LaitumkhrahShillong, Meghalaya -793 003. \\ ${ }^{2}$ Directorate of Environment, Imphal East - 795 010, Manipur. \\ *Directorate of Environment, Porompat, Imphal East-795 005, Manipur.
}

DOI : http://dx.doi.org/10.12944/CWE.8.1.10

(Received: March 22, 2013; Accepted: April 10, 2013)

\begin{abstract}
Documentation on water quality based on seasonal distribution pattern of physic-chemical characteristics of the three major rivers flowing in Imphal, Manipur were carried out during July, 2011 to June, 2012. Three main seasons were classified based on the ombothermicinformation for ten years weather data of Imphal. Significant seasonal variations of the different parameters were observed and the study has a great valuein terms of river ecosystem as well as water quality in different seasons.
\end{abstract}

Key words: Anthropogenic, Eutrophication, Allochthonous, Seasonal variation, River ecosystem, population growth, pollution.

\section{INTRODUCTION}

Water, by means of its physical, chemical and biological characteristics, reflects the significance as potent ecological factor and quality for sustenance. However, the increasing anthropogenic influences in recent years, in and around aquatic ecosystem and their catchment areas have contributed to a large extent to various nutrient enrichment which leads to deterioration of the water quality. The increasing trend of nutrient enrichment in the system accelerates eutrophication and growth of many aquatic organisms, which exerts a great surge to the ecosystem of many fresh water bodies. The very source of potable water contains both micro and macro nutrients in permissible limit but quality of drinking water changes due to human interference and get contaminated through percolation and seepage, drains and domestic sewage (Pandey and Kumar, 1995).

Now-a-days due to rapid industrialization and human population growth most of the Indian rivers are polluted (Sahu, 1991). The physicochemical characteristics are also greatly affected due to discharge of domestic, municipal, industrial and other several factors like religious offerings, recreational and constructional activities in the catchments areas ( Pandaet al.,1991). Hill and Webb (1958) reported that rainfall pattern influences in changing the physical and chemical environment of water and helps in increasing input of pollutants. Thus, necessary knowledge of the water quality for framing, restoration and management could result only after determining the distribution patterns of ever increasing enrichment of nutrients.

Therefore, the present investigation has been carried out with the objectives to assess the seasonal variation as well as water quality status basedon some physico-chemical characteristics of three major rivers of Imphal, Manipur.

\section{MATERIAL AND METHODS}

Samples for the characterization of different physico-chemical parameters were 
collected at monthly intervals from five (5) experimental sites of three rivers namely Imphal river, Nambulriver and Iril river within Imphal area of Manipur during July, 2011 to June, 2012. Water samples from different sites were collected by means of shallow water sampler in a polystyrene bottle. Some physico-chemical parameters like water temperature, conductivity, total dissolved solid, dissolved oxygen, free $\mathrm{CO}_{2}$ and $\mathrm{pH}$ were analyzed and recorded on the spots immediately after collection of the water samples. Analysis for the remaining physico-chemical parameters were carried out in thelaboratory. The methods used for the estimation of the variables were standard methods of APHA (1989) andTrivedy and Goel (1984).

For statistical analysis of seasonal variation, different seasons were classified according to ombrothermicinformation based on ten years data of air temperature, rainfall and humidity. Based on the informations, March to May is considered as summer season, June to October as rainy season and November to February as winter season.

Accordingly, the mean values of different parameters from five different sites of each river were used for the calculation of ANOVA (Analysis of variance) in different seasons. The methods of parker (1973) and Trivedi, Goel and Trisal (1987) were used in computing and analysis of ANOVA seasonally in different rivers.

\section{RESULTS}

The results of the physico-chemical analysis for five sites of three different rivers are depicted in table1-3. Values are mean for fivedifferent sites for each river during July, 2011 to June, 2012.

\section{Water Temperature}

Temperature of water of Imphal river ranges from $19.39^{\circ} \mathrm{C}$ (January) to $25.33^{\circ} \mathrm{C}$ (June) as compared to ranges of $21.00^{\circ} \mathrm{C}$ (January) to $26.34^{\circ} \mathrm{C}$ (August) of Nambul river and $19.50^{\circ} \mathrm{C}$ (January) to $25.43^{\circ} \mathrm{C}$ (July) of Iril river. Seasonally, the average maximum mean value was recorded as $25.02 \pm 0.75^{\circ} \mathrm{C}$ in Nambul river during rainy season and minimum as $20.82 \pm 1.34^{\circ} \mathrm{C}$ in Imphal river during winter season .

\section{Conductivity}

Average mean conductivity from all the sites of different rivers was found maximum during summer. Maximum value is $369.78 \pm 32.72 \mathrm{~m}$ Siemens $\mathrm{cm}^{-2}$ in Nambulriverand minimum value is during winter i.e. $94.50 \pm 22.60 \mathrm{mSiemens} \mathrm{cm}^{-2}$ in Iril river. Ranges of conductivity values from across the sites were67.33mSiemens $\mathrm{cm}^{-2}$ (Irilriver during January) to $401.33 \mathrm{mSiemens} \mathrm{cm}^{-2}$ (Nambul river during May).

\section{Total Dissolved Solid}

Total dissolved solid concentration from all the sites of different river varied from $40.67 \mathrm{mgl}^{-}$ ${ }^{1}$ (Imphalriver during January) to $181.94 \mathrm{mgl}^{-1}$ (Iril river during August). Highest concentration of T.D.S. was recorded as $131.59 \pm 31.74 \mathrm{mgl}^{-1}$ in Iril river during rainy season and minimum as 51.67 $\pm 7.93 \mathrm{mgl}^{-1}$ in Imphal river during winter.

\section{Turbidity}

Turbidity from all the sites of different rivers fluctuated from 18.40 NTU (Imphalriver during January) to 95.47NTU (Imphal river during September). Seasonally, the highest and lowest concentration of turbidity was recorded as 75.93 \pm 18.81 NTUinImphal river during rainy seasonand $20.98 \pm 2.15$ NTU in Imphal river duringwinter season .

\section{$\mathrm{pH}$}

The $\mathrm{pH}$ value of different river water shows a mark fluctuation for the different sites. The range of $\mathrm{pH}$ value shows a variation from 6.56 (Nambul river during January) and 8.36 (Nambul river during August). However, the highest average mean value was recorded as $8.01 \pm 0.26$ in Iril river during rainy season and lowest $6.78 \pm 0.20$ in Nambul river during winter season.

\section{Free $\mathrm{CO}_{2}$}

During the studies, Free $\mathrm{CO}_{2}$ concentration of the riversfor different sites also shows mark fluctuation. The ranges of Free $\mathrm{CO}_{2}$ were found to be fluctuated from $2.93 \mathrm{mgl}^{-1}$ (Irilriver during November) to $33.84 \mathrm{mgl}^{-1}$ (Nambul river during January). The average mean concentration of Free 


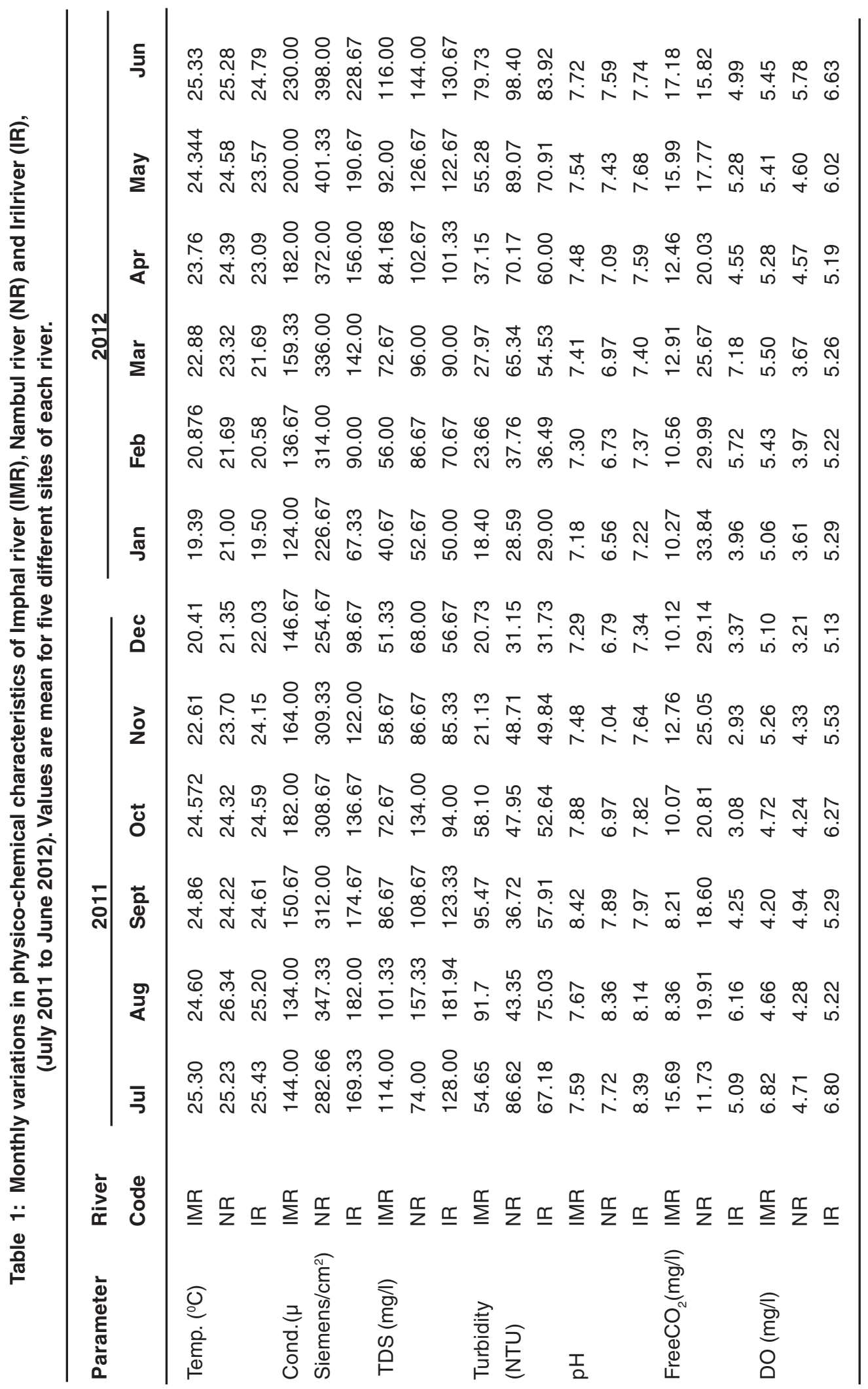




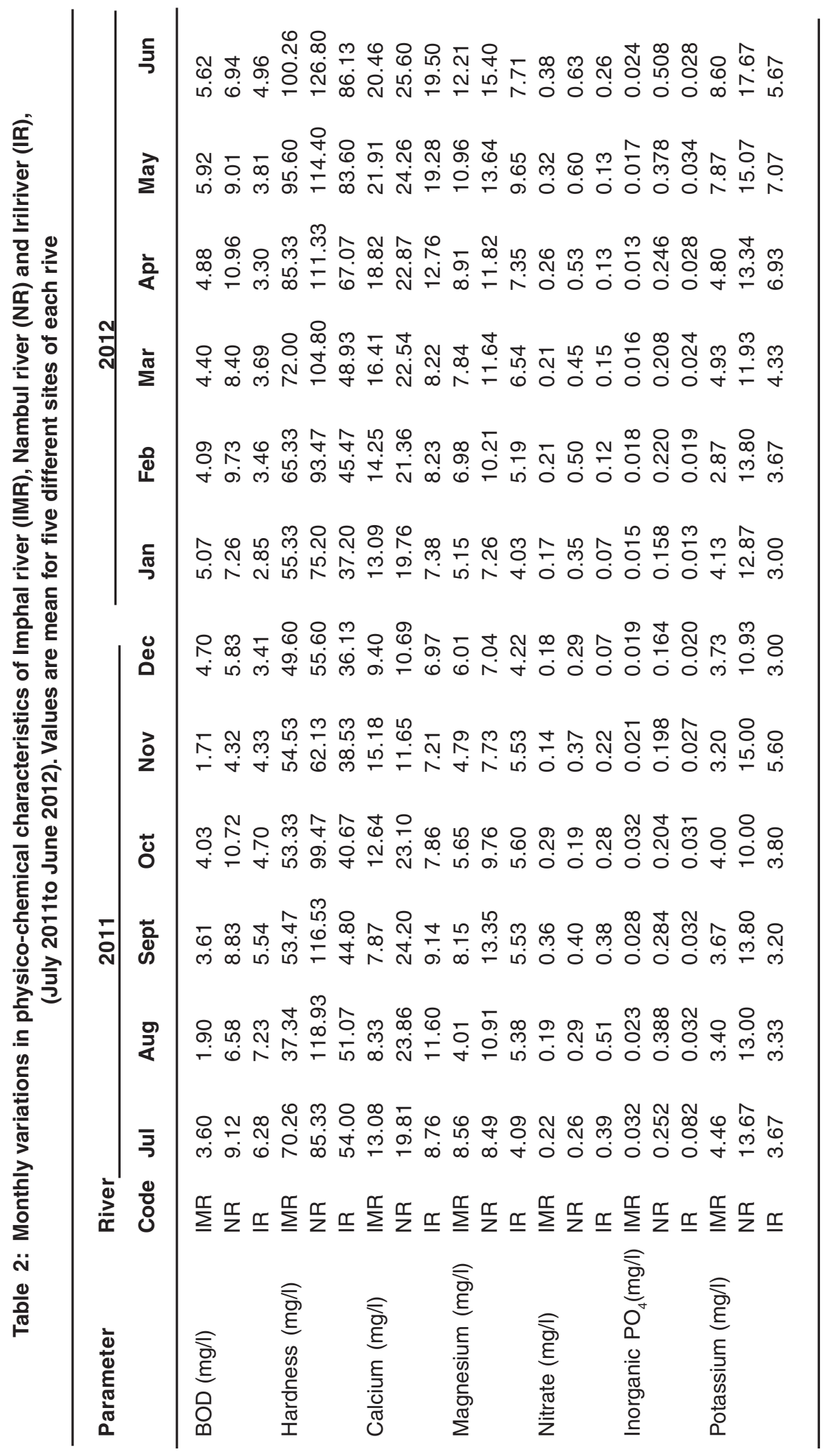


Table 3 :Seasonal variations in physico-chemical characteristic of Imphal river (IMR), Nambul river (NR) andlrilriver (IR), (July 2011 to June 2012).

Values are from the average mean of five different sites of each river

\begin{tabular}{|c|c|c|c|c|c|}
\hline Parameter & River Code & Summer & Rainy & Winter & Total Annual \\
\hline \multirow[t]{3}{*}{ Temperature $\left({ }^{\circ} \mathrm{C}\right)$} & IMR & $23.66 \pm 0.74$ & $24.93 \pm 0.37$ & $20.82 \pm 1.34$ & $23.24 \pm 2.03$ \\
\hline & $N R$ & $24.10 \pm 0.68$ & $25.02 \pm 0.75$ & $21.78 \pm 0.91$ & $23.71 \pm 1.64$ \\
\hline & $\mathrm{IR}$ & $22.78 \pm 0.98$ & $24.92 \pm 0.37$ & $21.57 \pm 2.01$ & $23.27 \pm 1.92$ \\
\hline \multirow{3}{*}{$\begin{array}{l}\text { Conductivity } \\
\left(\mu \text { simens } / \mathrm{cm}^{2}\right)\end{array}$} & IMR & $180.44 \pm 20.38$ & $168.13 \pm 38.96$ & $142.84 \pm 16.90$ & $162.78 \pm 30.79$ \\
\hline & $N R$ & $369.78 \pm 32.72$ & $329.73 \pm 44.56$ & $276.17 \pm 42.60$ & $321.89 \pm 53.15$ \\
\hline & $\mathrm{IR}$ & $162.89 \pm 25.06$ & $178.27 \pm 33.08$ & $94.50 \pm 22.60$ & $146.50 \pm 46.55$ \\
\hline \multirow[t]{3}{*}{ T.D.S. (mg/l) } & IMR & $82.95 \pm 9.72$ & $98.13 \pm 18.45$ & $51.67 \pm 7.93$ & $78.85 \pm 24.50$ \\
\hline & $N R$ & $108.45 \pm 16.13$ & $123.60 \pm 32.96$ & $73.50 \pm 16.44$ & $103.11 \pm 32.15$ \\
\hline & $\mathrm{IR}$ & $104.67 \pm 16.59$ & $131.59 \pm 31.74$ & $65.67 \pm 15.69$ & $102.88 \pm 36.91$ \\
\hline \multirow[t]{3}{*}{ Turbidity (NTU) } & IMR & $40.13 \pm 13.90$ & $75.93 \pm 18.81$ & $20.98 \pm 2.15$ & $48.66 \pm 28.31$ \\
\hline & $N R$ & $74.86 \pm 12.54$ & $62.61 \pm 27.90$ & $36.55 \pm 8.98$ & $56.99 \pm 24.23$ \\
\hline & $\mathrm{IR}$ & $61.81 \pm 8.34$ & $67.34 \pm 12.64$ & $36.77 \pm 9.25$ & $55.77 \pm 17.21$ \\
\hline \multirow[t]{3}{*}{$\mathrm{pH}$} & IMR & $7.48 \pm 0.07$ & $7.86 \pm 0.33$ & $7.31 \pm 0.12$ & $7.58 \pm 0.33$ \\
\hline & $N R$ & $7.16 \pm 0.24$ & $7.71 \pm 0.50$ & $6.78 \pm 0.20$ & $7.26 \pm 0.54$ \\
\hline & $\mathrm{IR}$ & $7.56 \pm 0.14$ & $8.01 \pm 0.26$ & $7.39 \pm 0.18$ & $7.69 \pm 0.35$ \\
\hline \multirow[t]{3}{*}{ FreeCO $_{2}(\mathrm{mg} / \mathrm{l})$} & IMR & $13.79 \pm 1.92$ & $11.90 \pm 4.23$ & $10.93 \pm 1.24$ & $12.05 \pm 2.99$ \\
\hline & NR & $21.16 \pm 4.07$ & $17.37 \pm 3.67$ & $29.51 \pm 3.61$ & $22.36 \pm 6.46$ \\
\hline & $\mathrm{IR}$ & $5.67 \pm 1.36$ & $4.71 \pm 1.14$ & $4.00 \pm 1.22$ & $4.71 \pm 1.29$ \\
\hline Dissolved & IMR & $5.40 \pm 0.11$ & $5.17 \pm 1.03$ & $5.21 \pm 0.17$ & $5.24 \pm 0.63$ \\
\hline \multirow[t]{2}{*}{ Oxygen (mg/l) } & NR & $4.28 \pm 0.53$ & $4.76 \pm 0.66$ & $3.78 \pm 0.48$ & $4.31 \pm 0.68$ \\
\hline & $\mathrm{IR}$ & $5.49 \pm 0.46$ & $6.04 \pm 0.74$ & $5.29 \pm 0.17$ & $5.65 \pm 0.61$ \\
\hline \multirow[t]{3}{*}{ B.O.D (mg/l) } & IMR & $5.07 \pm 0.78$ & $3.75 \pm 1.33$ & $3.89 \pm 1.51$ & $4.13 \pm 1.30$ \\
\hline & NR & $9.46 \pm 1.34$ & $8.44 \pm 1.70$ & $6.79 \pm 2.30$ & $8.14 \pm 1.99$ \\
\hline & $\mathrm{IR}$ & $3.60 \pm 0.27$ & $5.74 \pm 1.03$ & $3.51 \pm 0.61$ & $4.46 \pm 1.33$ \\
\hline \multirow[t]{3}{*}{ Hardness (mg/l) } & IMR & $84.31 \pm 11.83$ & $62.93 \pm 23.90$ & $56.20 \pm 6.59$ & $66.03 \pm 19.38$ \\
\hline & $N R$ & $110.18 \pm 4.90$ & $109.41 \pm 16.75$ & $71.60 \pm 16.70$ & $97.00 \pm 23.12$ \\
\hline & $\mathrm{IR}$ & $66.53 \pm 17.34$ & $55.33 \pm 17.99$ & $39.33 \pm 4.21$ & $52.80 \pm 17.25$ \\
\hline \multirow[t]{3}{*}{ Calcium (mg/l) } & IMR & $19.05 \pm 2.76$ & $12.48 \pm 5.06$ & $12.98 \pm 2.54$ & $14.29 \pm 4.55$ \\
\hline & NR & $23.22 \pm 0.91$ & $23.31 \pm 2.16$ & $15.87 \pm 5.47$ & $20.81 \pm 4.83$ \\
\hline & $\mathrm{IR}$ & $13.42 \pm 5.56$ & $11.37 \pm 4.75$ & $7.45 \pm 0.55$ & $10.58 \pm 4.47$ \\
\hline \multirow{3}{*}{$\begin{array}{l}\text { Magnesium } \\
(\mathrm{mg} / \mathrm{l})\end{array}$} & IMR & $9.24 \pm 1.59$ & $7.72 \pm 3.13$ & $5.73 \pm 0.98$ & $7.44 \pm 2.49$ \\
\hline & $N R$ & $12.37 \pm 1.11$ & $11.58 \pm 2.79$ & $8.06 \pm 1.46$ & $10.60 \pm 2.69$ \\
\hline & $\mathrm{IR}$ & $7.85 \pm 1.61$ & $5.662 \pm 1.30$ & $4.74 \pm 0.73$ & $5.90 \pm 1.67$ \\
\hline \multirow[t]{3}{*}{ Nitrate $(\mathrm{mg} / \mathrm{l})$} & IMR & $0.26 \pm 0.06$ & $0.23 \pm 0.08$ & $0.17 \pm 0.03$ & $0.24 \pm 0.078$ \\
\hline & NR & $0.53 \pm 0.08$ & $0.35 \pm 0.17$ & $0.38 \pm 0.09$ & $0.41 \pm 0.14$ \\
\hline & $\mathrm{IR}$ & $0.14 \pm 0.012$ & $0.36 \pm 0.10$ & $0.12 \pm 0.07$ & $0.23 \pm 0.14$ \\
\hline Inorganic & IMR & $0.015 \pm 0.002$ & $0.028 \pm 0.004$ & $0.018 \pm 0.001$ & $0.022 \pm 0.01$ \\
\hline \multirow[t]{2}{*}{ Phosphate(mg/l) } & $\mathrm{NR}$ & $0.277 \pm 0.090$ & $0.327 \pm 0.12$ & $0.185 \pm 0.029$ & $0.267 \pm 0.11$ \\
\hline & $\mathrm{IR}$ & $0.029 \pm 0.005$ & $0.041 \pm 0.023$ & $0.020 \pm 0.006$ & $0.031 \pm 0.02$ \\
\hline \multirow[t]{3}{*}{ Potassium (mg/l) } & IMR & $5.87 \pm 1.74$ & $4.83 \pm 2.15$ & $3.48 \pm 0.56$ & $4.64 \pm 1.79$ \\
\hline & NR & $13.45 \pm 1.57$ & $13.63 \pm 2.74$ & $13.15 \pm 1.72$ & $13.42 \pm 2.01$ \\
\hline & $\mathrm{IR}$ & $6.11 \pm 1.54$ & $3.93 \pm 1.00$ & $3.82 \pm 1.23$ & $4.44 \pm 1.49$ \\
\hline
\end{tabular}


$\mathrm{CO}_{2}$ was found to be highest in Nambul river during winter season i.e. $29.51 \pm 3.61 \mathrm{mgl}^{-1}$ and lowest 4.00 $\pm 1.22 \mathrm{mgl}^{-1}$ in Iril river during winter season. In the annual average, Free $\mathrm{CO}_{2}$ concentration was highest inNambul river than the other two rivers.

\section{Dissolved Oxygen(DO)}

Dissolved oxygen concentration was found to be fluctuated in each sites of the rivers and it was observed that averageconcentration was high in Iril river than the remaining two rivers. The ranges of dissolved oxygen varied from $3.21 \mathrm{mgl}^{-1}$ (Nambul river during December) to $6.82 \mathrm{mgl}^{-1}$ (Imphal river during July). Average mean concentration was found to be highest in Iril river during rainy seasion as $6.04 \pm 0.74 \mathrm{mgl}^{-1}$ and minimum of $3.78 \pm 0.48 \mathrm{mgl}^{-}$ ${ }^{1}$ in Nambul river during winter season.

\section{Biochemical Oxygen Demand}

Biochemical Oxygen Demand (BOD) values fluctuated from $1.71 \mathrm{mgl}^{-1}$ (Imphal river during November) to $10.96 \mathrm{mgl}^{-1}$ (Nambul river during April). Average BOD value shows highest in Nambulriverduring summer season i.e. 9.46 $\pm 1.34 \mathrm{mgl}^{-1}$ and lowest value as $3.51 \pm 0.61 \mathrm{mgl}^{-1}$ in Iril river during winter season.

\section{Hardness}

The concentration of hardness recorded minimum of $36.13 \mathrm{mgl}^{-1}$ (Irilriver during December) to $126.80 \mathrm{mgl}^{-1}$ (Nambul river during June). The average mean values of hardness from across the site of the rivers found maximum as concentration of $110.18 \pm 4.90 \mathrm{mgl}^{-1}$ in Nambul river during summer season and minimum value of $39.33 \pm 4.21$ $\mathrm{mgl}^{-1}$ in Iril river during winter season .

\section{Calcium}

The values range from $6.97 \mathrm{mgl}^{-1}$ (Irilriver during December) to $25.60 \mathrm{mgl}^{-1}$ (Nambul river during June). The average mean concentration of calcium was found to be highest in Nambul river during rainy season i.e. $23.31 \pm 2.16 \mathrm{mgl}^{-1}$ and lowest $7.45 \pm 0.55 \mathrm{mgl}^{-1}$ in Iril river during winter season. For annual average, the highest calcium value was observed in Nambulriveras compared to the remaining rivers.

\section{Magnesium}

The maximum value recorded was during summer i.e. $12.37 \pm 1.11 \mathrm{mgl}^{-1}$ in Nambul river and minimum during winter as $4.74 \pm 0.73 \mathrm{mgl}^{-1}$ in Iril river.Magnesium values from across the sites ranges from $4.01 \mathrm{mgl}^{-1}$ (Imphal river during August) to $15.40 \mathrm{mgl}^{-1}$ (Nambul river during June).

\section{Nitrate}

Nitrate concentration of the three river water of different sites ranged from $0.07 \mathrm{mgl}^{-1}$ ( Iril river, January and December) to0.63 $\mathrm{mgl}^{-1}$ ( Nambul river, June). Seasonally, the average maximum mean value was recorded as $0.53 \pm 0.08 \mathrm{mgl}^{-1}$ in Nambul river during summer season and minimum as $0.12 \pm 0.07 \mathrm{mgl}^{-1}$ in Iril river during winter season.

\section{Inorganic Phosphate}

The concentration ranges from $0.013 \mathrm{mgl}^{-}$ ${ }^{1}$ ( Iril river in January, Imphal river in April ) to 0.508 $\mathrm{mgl}^{-1}$ (Nambul river in June).Seasonal maximum mean value was $0.327 \pm 0.12 \mathrm{mgl}^{-1}$ (Nambul river in rainy season) and minimum as $0.015 \pm 0.002 \mathrm{mgl}^{-}$ 1 (Imphal river insummer season).

\section{Potassium}

The concentration of potassium in all the different sites of the river exhibits variation ranging from $2.87 \mathrm{mgl}^{-1}$ (Imphal river during February) to $17.67 \mathrm{mgl}^{-1}$ (Nambul river during June). The average seasonal maximum mean concentration of 13.63 $\pm 2.74 \mathrm{mgl}^{-1}$ of Potassium was observed in Nambul river during rainy season and minimum value of $3.48 \pm 0.56 \mathrm{mgl}^{-1} \mathrm{in}$ Imphal river during winter season. Annually, Nambulriver has got maximum concentration of Potassium than the other rivers.

\section{DISCUSSION}

Gradient in the water temperature is closely associated with ambient temperature (Munawar, 1970) and it is one of the most important factors because of its requirements in different metabolic activities of organisms in the ecosystem of different water bodies. In the present studies, the range of water temperature $\left(19.39^{\circ} \mathrm{C}\right.$ to $\left.26.34{ }^{\circ} \mathrm{C}\right)$ is very much comparable with finding of Srivastava and Singh (1995). The different thermal stratification at different rivers might be due to exposure to wind (Buckley and Sublette, 1964) and small difference between surface and bottom water temperature (Hickling, 1961; Sreenivason, 1968).Therefore, 
seasonal variation at different significant level of the three river shows at $p<0.05$ and $p<0.01$. However, insignificant variations were observed in Iril and Imphalriver during rainy season which might be due to lack of thermal exposure during rainy season.

Water conductivity is mainly attributed to the dissolved ions liberated from the decomposed plant matter (Sarwar and Majid, 1997) and input of organic and inorganic waste (Wright, 1982). In the present study, the significant level of conductivity in Iril and Imphal river was found always at $p<0.05$ and $p<0.01$ in all the seasons whereas in Nambul river significant level of $p<0.05$ was observed only during winter season. This pattern of variation was in support of the finding of Antwi and Ofori-Danson (1993) that liberation of ions results in the increase of conductivity. Total dissolved solids had a cyclic pattern of seasonal changes and maximum during rainy season and minimum in winter. This indicated that the dissolved materials were of allochthonous origin, which was brought into the river system with surface runoff. Johnson (1988) observed that total dissolved solid proportionately enhanced the electrical conductance in water and ran parallel to each other. In the present study, total dissolved solid concentration was found high during rainy season. However significant variation could not be well established during the season.

During the study water turbidity was found low during the winter season and high in rainy season. It might be due to the high silt content of the water carried down into the river by the feeder streams from the catchment areas. Therefore, this signifies the variation level of $p<0.05$ to $p<0.01$ in Imphal and Iril river. But, significant level of $p<0.01$ was observed only in winter season. According to Khan and Chowdhury (1994) high value of turbidity during rainy seasons may be due to heavy load of silt into the river water from the feeder streams.

Measurement of $\mathrm{pH}$ gives the intensity of acidic or basic nature of water. Changes in the $\mathrm{pH}$ of water may be the result of various biological activities (Gupta et al., 1996). If the water body is neither highly alkaline nor highly acidic, the $\mathrm{pH}$ of water is generally governed by the carbon dioxide - bicarbonate - carbonate system (Hutchinson,
1975). However fluctuation in $\mathrm{pH}$ is also related with input loads of pollutants in the river system (Sahuet al., 1995). The high value of $\mathrm{pH}$ during rainy season in the present work possibly resulted from increased rate of pollutant from the surrounding areas along with the rain water, but significant variation could not be established in this case also in all the seasons.

Free carbon dioxide present in water is mainly originated from the respiration of aquatic biota, decomposition of organic matters and infiltration through the soil. It is an input parameter of the buffer system and influences the concentration of carbonates, bicarbonates, $\mathrm{pH}$ and total hardness in water. Higher level of free carbondioxide during winter season may be attributed to increased decomposition rate under the river bed following slowdown of river water current. In the findings of Gupta et al.(1996) and Gupta and Mehrotra (1991) maximum value of free $\mathrm{CO}_{2}$ was found in the month of January and minimum in August. This is in gross agreement with the present finding that free $\mathrm{CO}_{2}$ values wererelatively higher in summer and winter. However, significant variation was observed in two rivers namely Imphal river and Iril river at $\mathrm{p}<0.01$ and $\mathrm{p}<0.05$ during rainy season only. For Nambul river actual significant level could not be established.

The rather high dissolved oxygen content during rainy season was largely attributed due to increase in aeration level with increasedflowcurrent of river water.Similar observation was also found by Gupta et al.(1996) that the DO content in river water is higher in monsoon as compared to summer season. The same result was also reported by Gupta and Mehrotra (1991). So, the present observation of higher DO level in rainy season than summer and winter is in conformity with the above findings by other researchers. Significant variation level at $p<0.01$ was found in two river(Imphal and Iril), but insignificant level of $p>0.05$ was observed in Nambul river.

Biochemical oxygen demand in water indicates the level of organic waste pollution. According to Akpataet al., (1993), microbial oxidization of organic sub-surface leads to the increase in the level of biochemical oxygen demand 
in water bodies. Das (1978) and Das and Pande (1980) reported that high organic materials deposition promotes natural oxidation and thereby depletion of oxygen occurs when anaerobic bacteria take over the process of decomposition. This increases in the value of biochemical oxygen demand level. Higher value during summer season might be due to biological as well as natural oxidation process with increase intemperature. Even though the significant variation could not be established, the BOD level in present observation was found high in summer than rainy and winter season in the three rivers.

Level of carbonates was higher during early monsoon i.e. during summer season of the present study, which is similar to the observation of Desai (1991). Kollman and Wali(1976), they observed that maximum value of carbonate was found during the month June which is early monsoon season and minimum during winter. Thus, the concentrations of hardness, calcium and magnesium were found higher during summer season and lower during winter season which is in agreement with the above findings. Significant variation was observed at $p<0.01$, during rainy season for the two river-Imphal and Iril, whereas for Nambul river it was observed to be at a level of $p>0.05$.

Higher concentration of nitrate was observed during summer and rainy season and lower concentration during winter which shows mark resemblance with the finding of Bhattacharya et al., (2002). In the present study, there was no significant variation in all the seasons.

Phosphorus is an important factor in ecological studies and often regarded as a limiting element in water ecosystem (Hecky and Kilhan,
1988). Both organic and inorganic forms are involved in transformation (Holtanet al.,1988). The high values of phosphate during rainy season might be due to transport from the surrounding catchment areas. Significant variation at the level of $p<0.05$ and $p<0.01$ were also observed during rainy season except for Nambul river. The low values of the nutrient during winter season might be probably due to lowering in input of pollutant in the river system which conforms the findings of Clarke (1924).

In general, concentration of potassium in natural waterislow, but high value being an indication of pollution by domestic waste (Trevedy\&Goel, 1984). Potassium value exhibit high during summer and rainy season and low during winter reason. It was due to rain runoff of decomposed plant materials from surrounding catchment area of the river, which help in increasing in the concentration of potassium in the water. In rainy season analysis of variance shows significance at a level of $p<0.01$ and $p<0.05$ for Imphal and Iril river whereas Nambul river at $p>0.05$ insignificance level.

\section{CONCLUSION}

The seasonal distribution pattern of different parameters were found to be influenced by different environmental factors for the three major rivers in Imphal valley. The presence of nutrient at different levels in the river water throughout the study period offer an excellent opportunity to characterize the quality of the water of the three major rivers in different seasons. This will be highly relevant because these three rivers are the main water resource for the people inhabiting around the Imphal city.

\section{REFERENCES}

1. Akpata, T.V.I., Oyenekan, J.A. and Nwanko, D.I., Impact of organic pollution on the bacterial, plankton and benthic population of Lagos lagoon, Nigeria.Intl. J. Eco. and Env. Sci.19: 73 - 82 (1993).
2. Antwi, L.A.K. and Ofori-Danson, P.K. Limnology of a Tropical Reservoir (The Kpong Reservoir in Ghana). Trop. Ecol. 34(1): 75-87 (1993).

3. APHA., Standard Methods for the 
Examination of Water and Waste Water Analysis, (17th Edn.), Washington D.C (1989).

4. Bhattacharya, A.K., Choudhuri, A., and Mitra, A., Seasonal distribution of nutrients and its biological importance in upper stretch of Gangetic West Bengal. Indian J. Environ. \& Ecoplan. 6(3): 421 - 424 (2002).

5. Buckley, B.R. and Sublette, J.E., Chironomidae (Diptera) of Louisiana II. The limnology of the upper part of Cane River Lake, Natchitoches Parish, Louisiana, with particular reference to the emergence of Chironomidae. Tulane Studies in Zoology 11(4): 151-166 (1964).

6. Clarke, F.W. , The data of Geochemistry (5th Edn.) Bull. U.S. Geol. Surv.770.U.S.Govt. printing offic, Washington D.C. 841 pp (1924).

7. Das, S.M., High Pollution in lake Nainital (U.P.) as evidenced by biological indicators. Science \& Culture 44: 236-237 (1978).

8. Das, S.M. and Pande, J., Pollution, Fish mortality and Environmental parameters in lake Nainital.J.Bombay Nat. Hist. Soc. 79: 100-109 (1980).

9. Desai, P.V., The impact of mining on the Mayem lake of Bicholim.Goa.In Current Trends in Limnology-1. 279 - 288 (1991).

10. Gupta, A.K. and Mehrotra, R.S., Ecological studies on water moulds of Kurukshetra. pp. 47-64. In. Current Trends in Limnology 1: 47-64 (1991).

11. Gupta, R.K., Sharma, M., Gorai, A.C. and Pandey, P.N., Impact of Coal Mining Effluents on the physico-chemical charactericts of Raja Tank, Jaria (Dhanbad).J. Freshwater Biol. 8(2): 63-73 .(1996).

12. V. Madgare, S.A. Iqbal, S. Pani and N. Iqbal., Orient J. Chem., 26(4): 1473-1477 (2010).

13. Hecky, R.E. and Kilhan, P., Nutrient limitation of phytoplankton in freshwater and marine environment. A review of recent evidence on the effect of enrichment. Limnol. Oceanogr. 33: 796-822 (1988).

14. Hickling, C.F., Tropical Inland Fisheries. Longman, London (1961).

15. Hill, M.B. and Webb, J.E., The ecology of Lagos lagoon II. The topography and physical feature of Lagos harbour and Lagonlagoon.Philosophical Transaction of the Royal Society of London 214(B): 319333 (1958).

16. Holtan, H., Kamp-Nielsen, L. and Stuanes, A.O., Phosphorus in soil, water and sediment: An Overview. Hydrobiologia 170: 19-34 (1988).

17. Hutchinson, G.E., A Treatise on Limnology. III. Limnological Botany. Willey, New York, U.S.A (1975).

18. Johnson, M.E.C., Total solid content in two freshwater lakes. Indian. J. Bot. 11(2): 188190 (1988).

19. Khan, M.A.G. and Chowhdury, S.H., Physical and chemical limnology of lakeKaptai, Bangladesh. Trop. Ecol. 35 (1): 35-51 (1994)..

20. Kollman and Wali., Inter seasonal variation in environmental and productivity relations of Potamogrtonpectinatus communities. Arch. Hydrobiol. Suppl. 50: 439-472 (1976).

21. Munawar, M., Limnological studies of freshwater ponds of Hyderabad, India. Hydrobiologia 36(1): 127-162 (1970).

22. Panda, R.B., Shau, B.K., Sinha, B.K. and Nayak, A., A comparative study and diurnal variation of physico-chemical characteristics of river, well and pond water at Rourkela Industrial Complex of Orissa.J. Ecotoxicol. Environ. Monit., 1(3): 206-217 (1991).

23. Pandey, R. and Kumar, A., Comparative evaluation of potable water quality of tribal and non-tribal villages of SantalPargana, Bihar. Ecol. Env. \&Cons. 1(1-4): 71-74 (1995).

24. Parker, R.E., Introductory Statistics for Biology.Edward Arnold (publisher) Ltd. 25Hill Street, London (1973).

25. Sahu, B.K., A study of the aquatic pollution load in the river Brahmani, Ph.D. Thesis, Sambalpur University, Sambalpur (1991).

26. Sahu, B.K., Rao, R.J. and Behera, S.K. Studies of some physic-chemical characteristics of Ganga river water (Rishikesh-Kanpur) within twenty four hours during winter,1994. Ecol. Env. \&Cons. 1(1-4): 35-38 (1995).

27. H.C. Kataria and S. Sharma., Orient J. Chem., 26(1): 337-338 (2010).

28. Sarwar, S.K. and Irfan-UI-Majid., Abiotic features and diatom population of Wularlake, Kashmir. Ecol. Env. \&Cons. 3(3): 121-12 (1997). 
29. Sreenivasan, A., Limnology of tropical impoundment IV: Studies of two hardwater reservoir in Madras state. Arch. Hydrobiologie. 65(2): 205-222 (1968).

30. Srivastava, G.K. and Singh, B.B. Observation of algal flora in relation to industrial pollution of Raptiriver at Gorakhpur. Ecol. Env. \& Cons., 1(1-4): 53-55 (1995).

31. Trivedy, R.K. andGoel, P.K. , Chemical and Biological Methods for water pollution studies. Environmental publication, Karad, 215 pp (1984).

32. Trivedy, R.K. ,Goel, P.K. and Trisal, C.L., Practical Methods in Ecology and Environmental Science. Environmental publication, Karad, 340 pp (1987).

33. Wright, R., Seasonal variation in water quality of a West African river (R. Jong in Sierra Leone). Revue d'HydrobiologieTropicale. 15(3): 193-199 (1982). 